\title{
Comment
}

\section{Japan - Countervailing Duties on Dynamic Random Access Memories from Korea (DS 336 and Corr.1, adopted 17 December 2007)}

\section{Prepared for the ALI Project on the Case Law of the WTO}

\author{
PAOLA CONCONI \\ Universite Libre de Bruxelles (ECARES) and CEPR
}

This dispute was sparked in January 2006, when Japan imposed a $27.2 \%$ countervailing duty on imports of dynamic random access memories (DRAMs) made by South Korea's Hynix, after calling into question whether financial support received by this chip producer constituted government subsidies.

In October 2001 and December 2002, existing creditors of Hynix - including banks partially or fully owned by the Korean government - agreed to bail out the company, by granting new additional credit and engaging in debt-for-equity swaps.

Japan argued that the Korean government breached WTO rules by covertly subsidizing Hynix, enabling it to set unfairly low prices for DRAM chips in the Japanese market, thus causing damage to domestic manufacturers. Korea argued that the bailout did not involve government subsidies. Negotiations failed to yield a resolution, and South Korea referred the case to the WTO in March 2006.

Crowley and Palmeter (2008) discuss various legal and economic issues concerning the Japan-DRAMs case. In my comments to their paper, I will focus on two of these issues: the evaluation of private investors' behavior and the issue of the injury caused by subsidized imports.

\section{Investors' behavior and government subsidies}

The key question in the Japan-DRAMs dispute was whether the government of Korea had 'entrusted or directed' private creditors to participate in the 
restructuring of Hynix, thereby providing a subsidy within the meaning of Article 1.1 of the SCM Agreement.

Japan argued that Hynix could not obtain additional funds on the commercial market; since the objective of both inside and outside investors is 'to maximize profits or minimize losses', 1 the participation of banks in the Hynix bailout must have been based on non-financial factors, such as the political pressure exercised by the Korean government. Korea countered that Japan's assessment was fundamentally flawed, since it evaluated the investment decisions of Hynix's creditors only from an outside-investor perspective. It claimed that inside investors might be willing to offer additional funds to an insolvent firm so as to minimize their losses.

In its ruling, the WTO dispute-settlement Panel upheld Japan's claim that the Korean government had 'entrusted or directed' certain of Hynix's creditors to participate in the October 2001 restructuring, contrary to Article 1.1(a)(1)(iv) of the SCM Agreement. The Appellate Body upheld the ruling concerning the 2001 bailout, arguing that the distinction between inside and outside investors is not useful when assessing whether or not a company is subsidized: There are no 'different standards applicable to inside and to outside investors. There is but one standard - the market standard - according to which rational investors act'. ${ }^{2}$

Crowley and Palmeter (2008) argue that the Appellate Body correctly dismissed the distinction between the investment perspectives of inside and outside investors with respect to insolvent companies: sunk cost should have no effect on the behavior of rational investors, whose decisions should only be based on the expected return or future profitability of a project, independently of previous expenditures.

Crowley and Palmeter point out one possible exception to this general principle, arising from the presence of asymmetric information among market participants: while fully informed inside investors might be willing to invest additional funds to bail out a company, uninformed or partially informed outside investors might not. The Korean government could have thus argued that, in a market characterized by informational asymmetries, it is reasonable to distinguish between the perspective of inside and outside investors. Though I agree with Crowley and Palmeter on this point, I believe that various other arguments could be used to support the relevance of sunk costs and thus the distinction between inside and outside investors.

A first set of arguments comes from rational choice theory. Various studies have shown that, contrary to conventional wisdom, it can sometimes be rational for individuals to condition behavior on sunk costs. For example, in a world of random returns, the realization of a return is informative about the expected value of continuing a project; a large loss, which leads to a rational inference of a high variance, will often lead to a higher option value, since option values tend to rise

1 Japan's appellant's submission, para. 187.

2 Appellate Body Report, Japan-DRAMs (Korea), para. 172. 
with variance. There can thus be an option value to maintaining investments (e.g., Dixit, 1992; Dixit and Pindyck, 1994). Rational investors may also 'throw good money after bad money' for reputational concerns: abandoning a project may reveal that an agent is a bad forecaster, leading agents to rationally persist with bad projects to conceal their poor skills (e.g., Prendergast and Stole, 1996; Camerer and Weber, 1999). A vast literature in corporate finance has also shown that financial constraints on firm managers improve agency problems. ${ }^{3}$ However, managers with a limited budget may rationally invest more in a project, rather than less, since their ability to undertake alternative investments declines in the level of sunk costs.

A second set of arguments for the relevance of sunk costs and the distinction between inside and outside investors comes from behavioral economics. In particular, Thaler (1980) provides an explanation for sunk-cost effects based on the prospect theory developed by Kahneman and Tversky (1979), according to which people react to losses by investing more because of loss aversion.

Therefore, there are both rational and behavioral reasons for why individuals may condition their investment choices on previous expenditures. Irrespective of the theoretical rationale for this investment behavior, there exists ample empirical evidence on the 'sunk cost fallacy'. For example, in the studies of Arkes and Blumer (1985) and Whyte (1993), subjects were presented with different information on a business investment project. One group of subjects was told that a large amount had already been invested, while another group was told that a small amount had already been invested. In almost all the cases, individuals with the large sunk investment chose to invest more. ${ }^{4}$

The above discussion implies that governments complaining against the use of CVDs may, in the future, try to reestablish the inside investor-outside investor distinction, against the type of reasoning supported by the $\mathrm{AB}$ in the Japan$D R A M s$ case. They may argue that inside investors may rationally behave differently from outside investors, due to asymmetric information, reputational concerns, financial constraints, or other reasons. Alternatively, they may claim that investors often behave irrationally, 'spending good money chasing bad money'. Both lines of argument suggest that the fact that a company receives additional funding from previous investors - while it is unable to obtain funding on the commercial market - is not necessarily proof of government intervention.

3 On the theoretical side, see among many others, Stiglitz and Weiss (1981) and Hart and Moore (1995). On the empirical side, only a small fraction of business investment is financed by borrowing (see Fazzari and Athey, 1987; Love, 2003).

4 There is evidence that sunk costs also influence consumption decisions. For example, in a field experiment with season tickets to the Ohio University's Theater in 1982, Arkes and Blumer (1985) found that people who were charged the regular price at the ticket counter attended 0.83 more plays on average, out of the first five plays of the season, than those who received an unexpected discount. 


\section{Causation of injury}

Another important issue in the Japan-DRAMs dispute involves the test for the causation of injury. The Appellate Body upheld the Panel's finding that the Japan investigating authority did not act inconsistently with Articles 15.5 and 19.1 of the SCM Agreement by not establishing separately that the allegedly subsidized imports were, 'through the effects of subsidies', causing injury within the meaning of the SCM Agreement.

Crowley and Palmeter (2008) argue that the Appellate Body's ruling weakens the requirement of a causal link between subsidies and countervailing duties and is highly undesirable since it can lead to protectionist abuse of the SCM Agreement. In their view, the size of the import restriction should be commensurate with the magnitude of the injury caused by the subsidy, and the mere presence of injury is insufficient for determining the appropriate magnitude of a countervailing duty. Ideally, the test for causation of injury should involve the use of econometric models to quantify the effects of a subsidy on prices and quality, to make sure that CVDs are calibrated to precisely offset the effects of subsidies.

Even though I understand the concerns expressed by Crowley and Palmeter, I will argue that making the causality test more severe may not be necessary or desirable in the case of injury caused by subsidized imports.

First, previous cases suggest that the risk of abuse of CVDs is too serious. This is because injury determination is far from being straightforward, requiring formal evidence disentangling the various factors that may have caused injury. For example, in the United States-DRAMS dispute, the Appellate Body ruled that the US's injury determination suffered from two key flaws: first, the US did not separate the effects of Hynix DRAMs from Samsung DRAMs; second, it did not properly assess the overall condition of the domestic industry in light of the weak market demand (see Prusa, 2008).

Perhaps more importantly, the Appellate Body's stance on the issue of causation of injury may reflect the delicate balance between deterring the use of subsidies and deterring the use of countervailing duties, which is at the heart of the SCM Agreement. Strengthening the causal link required between subsidies and countervailing duties could thus have the effect of weakening the discipline imposed on the use of subsidies.

In this respect, it is interesting to note that the requirements for the causation of injury are much stricter in the case of safeguard measures, to the point that 'no nation can employ them without the near certainty of defeat in the dispute resolution process should they be challenged' (see Grossman and Sykes, 2007). The difference in the stringency of the injury test may be due to the fact that, in the case of safeguard measures, regulation is only aimed at avoiding protectionist abuses; in the case of 'unfair trade' measures, like countervailing duties and antidumping duties, regulation must instead deter both protectionist abuses by 
governments in importing countries and unfair market practices by governments or private entities in exporting countries.

\section{References}

Arkes, Hal R. and Catherine Blumer (1985), 'The Psychology of Sunk Cost', Organizational Behavior and Human Decision Processes, 35 : 124-140.

Camerer, Colin F. and Roberto A. Weber (1999), 'The Econometrics and Behavioral Economics of Escalation of Commitment: A Re-examination of Staw and Hoang's NBA Data', Journal of Economic Behavior and Organization, 39: 59-82.

Crowley, Meredith A. and David Palmeter (2008), 'Japan - Countervailing Duties on Dynamic Random Access Memories from Korea', forthcoming in World Trade Review 2009:1, and in Henrik Horn and Petros C. Mavroidis (eds.), The American Law Institute - The WTO Case Law of 2006-2007: Legal and Economic Analysis, Cambridge: Cambridge University Press.

Dixit, Avinash K. (1992), 'Investment and Hysteresis', The Journal of Economic Perspectives, 6: 107-132.

Dixit, Avinash K. and Robert S. Pindyck (1994), Investment under Uncertainty, Princeton, NJ: Princeton University Press.

Fazzari, Steven M. and Michael J. Athey (1987), 'Asymmetric Information, Financing Constraints, and Investment', The Review of Economics and Statistics, 69: 481-487.

Grossman, Gene M. and Alan O. Sykes (2007), 'WTO Case Law: The American Law Institute Reporters' Studies, United States - Definitive Safeguard Measures on Imports of Certain Steel Products', World Trade Review, 6: 89-122.

Hart, Oliver and John Moore (1995), 'Debt and Seniority: An Analysis of the Role of Hard Claims in Constraining Management', The American Economic Review, 85 : 567-585.

Kahneman, Daniel and Amos Tversky (1979), 'Prospect Theory: An Analysis of Decision Under Risk', Econometrica, 47: 263-291.

Love, Inessa (2003), 'Financial Development and Financing Constraints: International Evidence from the Structural Investment Model', The Review of Financial Studies, 16: 765-791.

Prendergast, Canice and Lars Stole (1996), 'Impetuous Youngsters and Jaded Old-Timers: Acquiring a Reputation for Learning', Journal of Political Economy, 104: 1105-1134.

Prusa, Thomas J. (January 2008), 'Comment on "US - Countervailing Duty Investigation of DRAMS", by Francois and Palmeter', World Trade Review, 7: 231-234.

Stiglitz, Joseph E. and Andrew Weiss (1981), 'Credit Rationing in Markets with Imperfect Information', The American Economic Review, 71: 393-410.

Thaler, Richard H. (1980), 'Toward a Positive Theory of Consumer Choice', Journal of Economic Behavior and Organization, 1: 39-60.

Whyte, Glen (1993), 'Escalating Commitment in Individual and Group Decision Making: A Prospect Theory Approach', Organizational Behavior and Human Decision Processes, 54: 430-455. 